\title{
BETWEEN LANGUAGE MAINTENANCE AND LANGUAGE SHIFT: THE SLOVENIAN COMMUNITY IN ITALY TODAY AND TOMORROW
}

\author{
Devan Jagodic \\ Slovene Research Institute - SLORI
}

\begin{abstract}
The paper focuses on the processes of language maintenance and shift among the Slovenian community in north-eastern Italy, from both the present and future perspectives, and presents the results of two empirical studies. The first offers a quantitative analysis of the linguistic behaviour of the Slovenian community members, in order to provide information about the level of minority language maintenance or the gradual shift towards Italian. The intergenerational comparison brings into focus some divergences among two different age groups and indicates the variables that cooperate to establish them. The second study explores the challenges that the Slovenian community must face in order to encourage the use of the minority language among non-Slovenian speakers. Relying on qualitative data obtained by a series of in-depth interviews with representatives of Slovenian political, cultural and economic organizations in Italy, the study aims to identify some possible strategies for the spread and promotion of the Slovenian language among the wider society.
\end{abstract}

Keywords: Minority Languages, Language Maintenance and Shift, Language Use, Language Planning, Slovenian Community in Italy, European Integration

\section{Introduction}

Particularly common phenomena in bilingual and multilingual societies are the so called processes of language shift, when a group progressively abandons its language of origin, at the same time adopting the language of the socially or economically dominant group (Fishman 1971, Baker-Jones 1998). The process of language shift does not finish at the end of the life of a person or of a group of people; rather it gradually develops from generation to generation (Fasold 1984). In such situations, the members of a group start using the more prestigious language in a series of progressively higher number of domains and communicative situations. 
The social factors leading to the abandonment of minority languages are many, of different type and usually interrelated (Baker-Jones 1998, Crystal 2000, De Klerk 2000). In this light we refer to demographic factors - as for example the number of the minority language speakers and their concentration in the settlement area - the diffusion of linguistically mixed marriages within the minority group, the status and the prestige of the language on a local and international level, the existing institutional support of the minority language, the intensity of the economic pressure deriving from the wider society, and so on.

The paper approaches the issue of language maintenance and shift among the Slovenian minority group in the Friuli Venezia Giulia Region (north-eastern Italy). The first section will offer an illustration of the present situation. After a brief depiction of the sociolinguistic profile of the Slovenes living in this area, the results of a study examining their linguistic behaviour in everyday life will be discussed. The quantitative analysis of the language use patterns among two generations of Slovenian community members will contribute to identify the factors that might lead to a progressive shift towards the use of the Italian majority language. The second section concentrates on the efforts that the Slovene community shall undertake in order to hinder the language shift processes and adopt a perspective for the acquisition of new potential speakers. In the light of the opportunities offered by social and political changes in the Italian-Slovenian border area in recent years, some possible strategies for the spread and promotion of the minority language among the wider society will be explored. The analysis will rely on some qualitative data obtained by a series of in-depth interviews with qualified observers of the Slovenian minority dynamics.

\section{The Slovenian community in Italy today}

\subsection{Sociolinguistic portrait}

Slovenes living in Italy are one of the Slovenian autochthonous communities living outside the Republic of Slovenia proper. They live along the Italian-Slovenian border covering an area of about 1500 square kilometers in the Provinces of Udine/Videm, Gorizia/ Gorica and Trieste/Trst. Slovenes are settled in 39 municipalities of 
the Friuli Venezia Giulia Region. Most of them live in the urban environments of Trieste/Trst and Gorizia/Gorica, but their presence is very strong in (especially) surrounding municipalities. There is no official record of the size of the Slovenian community in Italy, nor the geographic coverage of the Slovenian language. However, on the basis of a survey conducted in 2002 by the Slovene Research Institute (SLORI), it is estimated that the population of Slovenian nationality is about 95,000 people, 100,000 are Slovenian speakers, while 183,000 people understand Slovenian (Bogatec 2004).

The right to use Slovenian in public life is regulated by several pieces of legislation arising from national and regional laws, municipal statutes and acts of international law. The National Law 38/2001 "Legal Provisions for the Protection of the Slovenian Linguistic Minority in Italy" fully regulates the use of the minority language in public administration, elected bodies, public education and toponomy, while the more recently adopted Regional Law 26/2007 further integrates the national provisions. Brezigar (2009), however, underlines the "liberal" taste of this legal framework, as it limits itself in establishing possibilities and opportunities for the use of the minority language, but does not impose on authorities the duty of creating a bilingual environment wherein all inhabitants would be able to use the language of their choice in most communicative situations.

From a sociolinguistic point of view, the Slovenian community indeed lives in a context of unilateral social bilingualism. This means that, although the Slovenian component is bilingual - as the knowledge of the Italian language is necessary in everyday life the vast majority of the Italian population has no knowledge of the minority language, not even at the receptive level. This imbalance in the distribution of language competences among the population makes the minority language an almost exclusively intra-group code (Kauèiè-Baða 1997). Especially in the urban areas of Trieste/Trst and Gorizia/Gorica its out-of-family use is restricted to some typical "minority domains", such as the state schools with Slovenian as the language of instruction ${ }^{1}$ and the institutions that belong to Slovenes or are intended for them (political, cultural and sport associations, theatres, libraries, etc.). Being the language of commu-

"Slovenian schools" are a constituent part of the Italian school system and dependant on the Italian Ministry of Public Education. The instruction is based on the same curriculum that is used in the schools with the Italian medium of instruction but takes place in the Slovenian language. 
nication in shops, offices, restaurants and many other social domains, the Italian language is prevalent, and often even the exclusive code in public life.

\subsection{The Slovenian community between lan- guage maintenance and language shift}

\subsubsection{Aims and method of the quantitative study}

In the following pages the language use patterns among the Slovenian population in Italy will be analysed in accord with the results of a survey carried out in 2006 by the Slovene Research Institute. The quantitative study took into consideration 200 subjects resident in the province of Trieste/Trst who identify themselves as members of the Slovenian community. The interviewees belonged to two different age generations: the first consisted of 100 subjects 35 and 36 years old ${ }^{2}$, while the second generation included 100 subjects between 16 and 20 years old ${ }^{3}$. The data have been obtained through a series of interviews based on a structured questionnaire. The aim of the interviews was to collect information on the use of the minority language (Slovenian) and the majority language (Italian) according to a series of social domains. The initial hypothesis was that the many disparities between the two languages might boost a progressive advancement of the processes of shift towards the Italian language.

\subsubsection{Results}

The questionnaire included a list of items asking interviewees to indicate which language they use in a series of communicative situations. The latter have been subsequently gathered in seven major domains in order to define those promoting the maintenance of the minority language and those boosting the language shift.

2 The older generation includes subjects who finished the lower secondary school with Slovenian as the language of instruction in the school year 1983/84.

3 The subjects of the younger generation were attending the third or fourth year of the upper secondary school with Slovenian as the language of instruction in the school year 2005/2006. 
On the one hand, the results emphasize how the use of the minority language is still dominant in the more intimate and informal situations. The family, in particular, still remains the "rampart" of preservation of the native language, as the vast majority of the interviewed subjects has declared that they use it exclusively or mostly in the relations with all its constituent elements (Figure 1). The only partial exception is to be found in the level of interpenetration of the Italian language in the interactions of the interviewees with their partners, which is explained by the consistent presence of exogamic relations within the analyzed sample. However, it is interesting that among the same subjects with Italian speaking partners, no one has stated that they speak mainly Italian with their children. The loyalty towards the use of the minority language within the mixed family structures seems to guarantee - at least in the short-medium term - its intergenerational transmission.

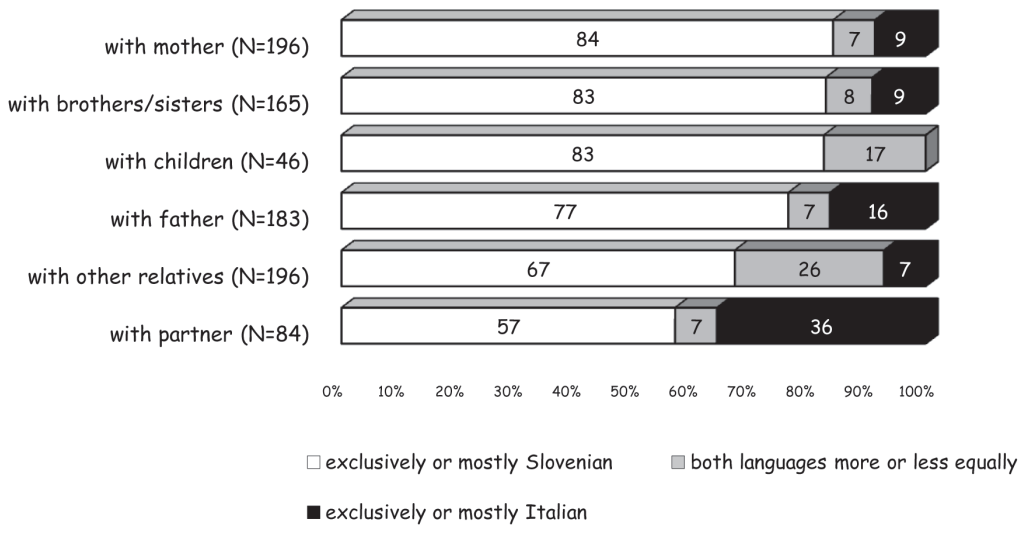

Figure 1. Language use in the family domain.

In the two following domains under analysis, in the field of acquaintances (Figure 2) and in the cultural, sports and religious lives (Figure 3 ) of the interviewed subjects, the minority language also seems to maintain its vitality. The importance of the Slovenian associations and other organizations of the civil society must be highlighted, as they are not just places where young community members meet in their free time, but also represent spaces where Slovenes can speak their mother tongue. 


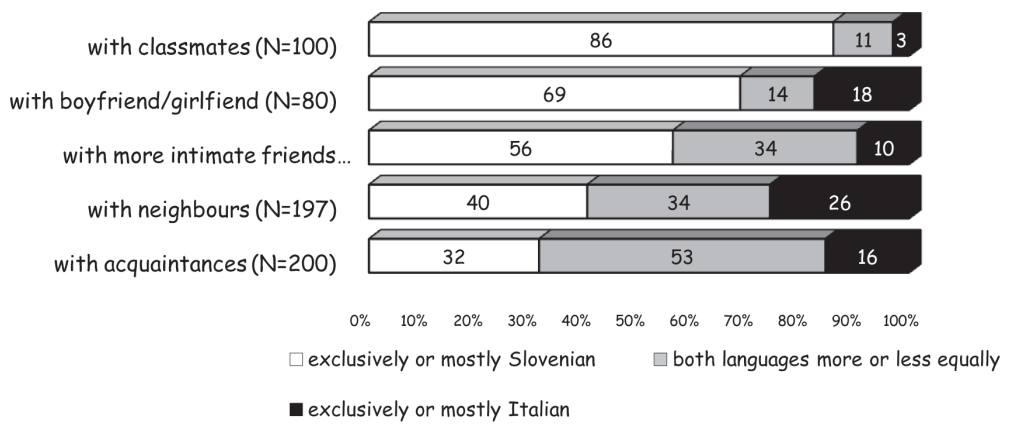

Figure 2. Language use in the domain of the acquaintances.

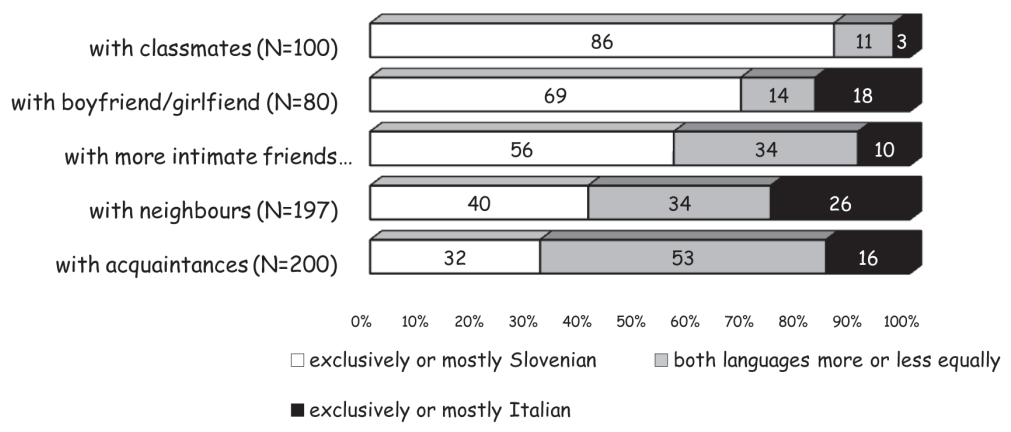

Figure 3. Language use in cultural, sports and religious life.

Nevertheless, the results clearly show how, as the social spheres move from the private to the public-institutional, the use of the Italian language tends to prevail over the Slovenian. More formal communicative situations induce the participants to respect the communicative rules, existing in the local society, in such a way boosting the use of the only code recognized as "official", which is obviously the Italian language.

This consideration emerges first of all from the results related to the language behaviour in the working place (Figure 4), as most Slovene speakers are employed in Italian-speaking environments, where they lack opportunities for the use of the native language. In working contexts, the use of Slovenian is indeed banished to entrepreneurial structures managed by the minority, to some public institutions and to limited companies conducting their business with Slovenian partners or clients. 


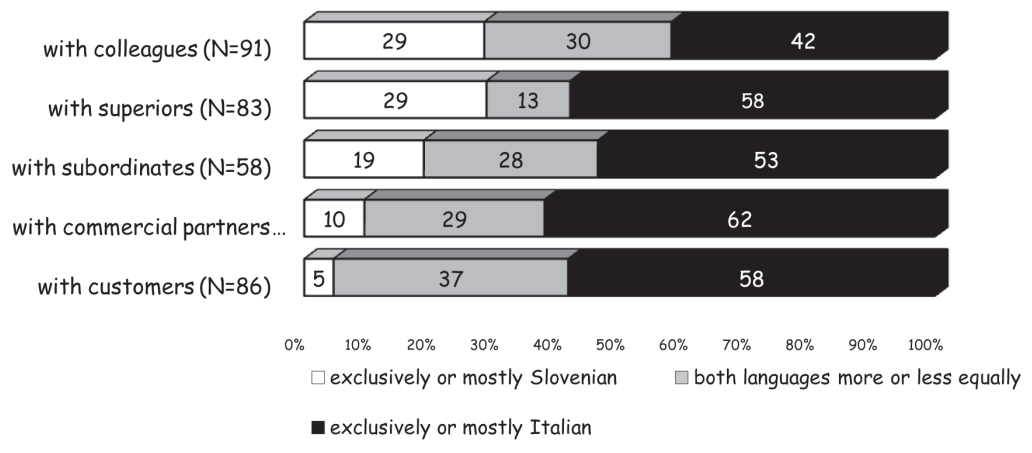

Figure 4. Language use in the working place.

The use of the Italian language also tends to prevail in the interactions with professionals and service providers (Figure 5), shopkeepers and public locale managers (Figure 6), and civil servants (Figure 7). In these domains, the choice of the code to be used is linked to a series of environmental circumstances set by the communicative event. Indeed, as a general rule, Slovenian speaking citizens tend to speak Italian in public offices and locales in the urban area, whereas in rural surroundings the same citizens choose the minority language. A second factor, which restrains the use of the latter in public life, coincides with the paucity of written notices on the territory (place-names, shops' and public locales' signs) in the Slovenian language. Such a lack of signs is not to be ascribed only to the local authorities' non-fulfillment of the legal framework provisions, but also to the minority members, who are not careful enough regarding rendering "visible" their language in the territory.

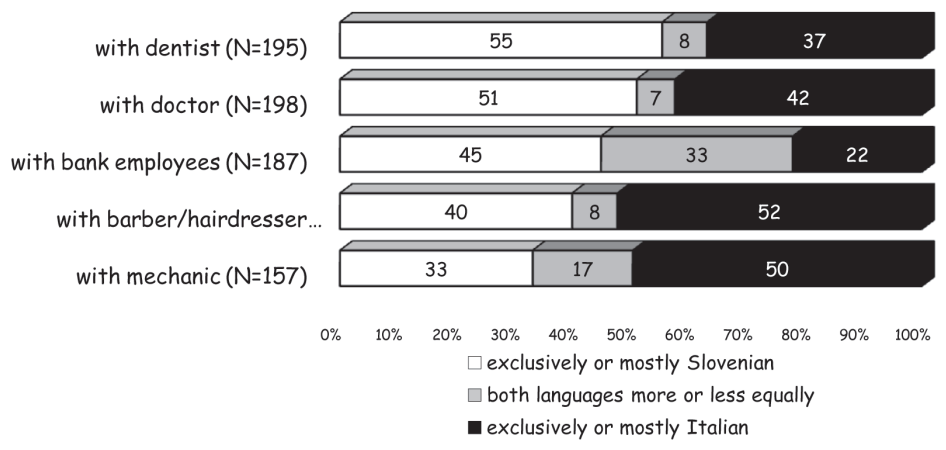
viders.

Figure 5. Language use with professionals and service pro- 
with library staff ( $\mathrm{N}=192)$

with grocery personell $(\mathrm{N}=197)$

with newsagents ( $N=186)$

with waiters $(\mathrm{N}=198)$

with bartenders $(\mathrm{N}=196)$

with night-club staff $(\mathrm{N}=135)$

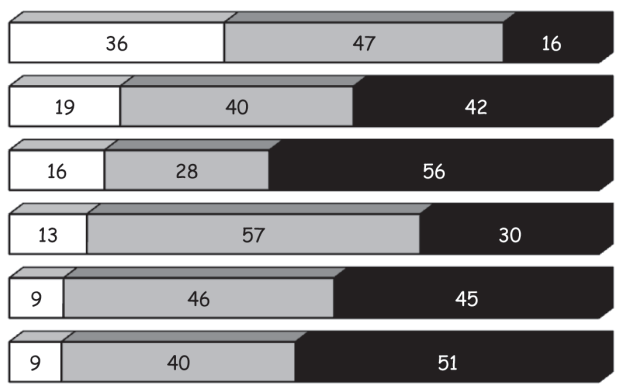

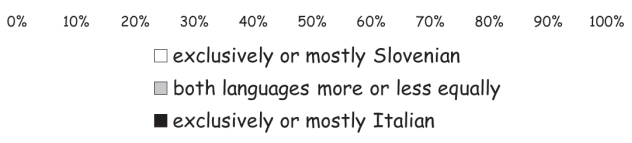

Figure 6. Language use with the shopkeepers and public locale managers.

with municipal employees $(N=182)$

with post office employees $(N=188)$

with bus drivers and conductors ( $\mathrm{N}=138)$

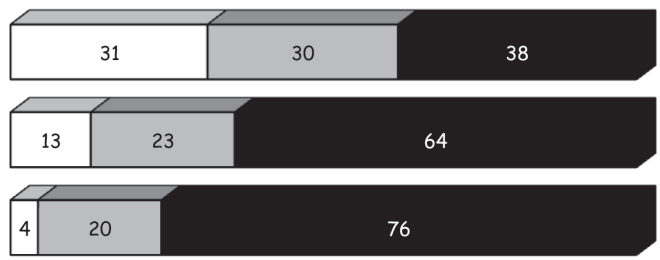

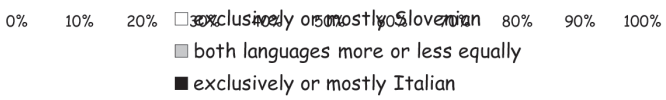

Figure 7. Language use with civil servants in public administration.

From the comparison of the results regarding the two analysed language generations some statistically relevant differences arise. These concern the different patterns of language use especially in the domain of acquaintances, where the Slovenian language is more widespread among the older generation (35-36 years old), compared to the younger (16-20 years old). It seems that the switch from school to work or to university studies coincides with a change in the social networks of the individuals, whose acquaintances grow among people with a different mother tongue than theirs. It is during this step that language use patterns of the Slovene minority members undergo a change towards a gradual progress of Italian language use. 
switch from school to work

- change of linguistic networks propensity towards language shift

Along with the age factor, the data analysis has identified some other variables that seem to play a role in the promotion of language maintenance or, vice-versa, language shift. The results have first of all highlighted how a good knowledge of the mother tongue and a strong affection for the minority ethnic group are two elements that favour the use of the Slovenian language. Another key factor, which is typical of the studied area, in view of the already mentioned differences between a prevalently Italian speaking urban environment and a prevalently Slovenian speaking surroundings, is obviously the subjects' place of residence. Finally, the gender factor also seems to play a relevant role, as women have revealed a stronger inclination to language shift than men.

\begin{tabular}{|cc|}
\hline FACTORS ENCOURAGING & FACTORS ENCOURAGING \\
LANGUAGE MAINTENANCE & LANGUAGE SHIFT \\
\hline High language competence & Low language competence \\
\hline $\begin{array}{c}\text { Strong identification with the } \\
\text { minority group }\end{array}$ & $\begin{array}{c}\text { Weak identification with the } \\
\text { minority group }\end{array}$ \\
\hline Residence in rural surroundings & Residence in urban environment \\
\hline Male gender & Female gender \\
\hline
\end{tabular}

\section{The Slovenian community in Italy tomorrow}

\subsection{New socio-political backgrounds, new development opportunities}

The results of the quantitative study demonstrate how the Slovenian community in Italy might be considered as a typical example of a rather slow, but progressive substitution of the native language by the socially and economically dominant language. The threat of a gradual abandonment of the minority language appears to be even more severe in a time of increasing globalisation, which bear an overpowering drives towards uniformity and standardisation of cultural models, supported by the impulse of newer media technologies. Now more than ever before, the efforts towards suit- 
able language planning activities, which are not oriented only at maintaining the use of the minority language among the community members, but which also aim at the enlargement of the traditional minority target audiences.

In this regard, the social and political changes brought about by the admission of the Republic of Slovenia into the European Union and the Schengen area offer a concrete chance to the Slovenian community to exploit some new development opportunities. The political and economic growth of Slovenia in recent years, along with the recognition of its language as one of the official languages of the EU, has contributed to increasing the social prestige of the Slovenian language in the Friuli Venezia Giulia Region. The physical abolition of the Italian-Slovenian administrative border has facilitated the mobility of people, goods, services and capital, thus contributing to the creation of new opportunities (working, study opportunities), linked to the knowledge of Slovenian. Such "pragmatic" opportunities seem to have increased the motivation of non-Slovenian speakers to acquire the minority language.

The aforementioned changes call for a thorough revision of the future strategies of the Slovenian community in Italy, which will be the object of analysis in the following pages. In particular, it will be verified whether the community is ready to seize the challenges generated by the new socio-political backgrounds and to adopt a new development perspective that will go beyond the mere maintenance of the status quo.

\subsection{Strategies for acquisition of new potential Slovenian speakers}

\subsubsection{Aims and methods of the qualitative study}

Relying on the results of a second study carried out by the Slovene Research Institute (Bajc et al 2008), some possible strategies for the spread and the promotion of the minority language knowledge and use among non-Slovenian speakers will be explored. The qualitative study entailed 54 in-depth interviews with qualified observers of the minority dynamics: Slovenian elected political representatives, mayors, leaders of the minority civil society organizations, economists, journalists, workers in the fields of informal edu- 
cation, sports, culture, etc. The qualified observers have been questioned about the strategies the Slovenian community should pursue in order to acquire new potential speakers within the wider society.

The methodology of the research required the recording of the interviews, their transcription and analysis. In the following pages only those extracts of the interviews that are relevant for the purposes of the present paper will be presented. The language of the interviews was Slovenian, while the extracts have been translated into English. The missing parts of the texts are marked with three periods within brackets.

\subsubsection{Results}

The analysis of the 54 interviews has identified five main strategies highlighted by the qualified observers for the spread and the promotion of the minority language among non-Slovenian speakers:

A) A professional approach towards the inclusion of non-Slovenian speaking pupils in the primary schools with Slovenian as the language of instruction and towards their acquisition of the minority language.

State schools with Slovenian as the language of instruction represent one of the fundamental factors encouraging minority language vitality. In recent years, the ethno-linguistic structure of the "Slovenian" school population has radically changed, as the percentage of children from mixed marriages and non-Slovenian families has increased considerably.

Most of the interviewed subjects consider the recent changes in the school structure as an "opportunity" to acquire new potential speakers of the minority language and perhaps future members of the minority group. The latter is therefore called to invest its resources in trying to retain the newly enrolled pupils and help them integrate into the new linguistic environment.

Int. 37: (...) We are all aware how precious this is, something we could only dream about 20 years ago, (...) that the majority community would show such an interest in the Slovenian school. (...).

Int. 39: (...) I think that we need a modern approach. Accept them [= non-Slovenian speaking pupils] as something very positive for the community, and work on this factor. (...) 
The collected testimonies point out how the didactic programmes and the methodologies adopted by the Slovenian schools are often inadequate or at least improvised. There is a need for a more professional approach, which has to be based on high school qualification and constant training of teaching and pedagogical staff.

Int. 50: I think that this is an opportunity and an enrichment, even if it requires an additional effort on behalf of the teachers, and the majority of them are not ready. (...) Probably every single teacher has found some didactical strategies and methods to use in order to cope with the situation. But we feel the lack of coordination and of united work. (...)

Int. 28: (...) The schools surely have determined techniques, which facilitate the integration of these pupils into the school tissue. (...) This means that the university shall offer training for this, or maybe specialized courses, which are compulsory to gain qualification as a teacher. A scientific approach, without improvisation, is needed.

Particular care should be dedicated to stimulating nonSlovenian pupils and parents to supplement their studies of the Slovenian language and to their integration into out-of-school activities offered by Slovenian institutions and organizations.

Int. 25: I think that parents should have the opportunity to be involved in our community, maybe with courses of Slovenian language in schools, with various tangible initiatives, such as visits to our organisations, where the parents can see that they can enroll their children in these organisations. (...)

Nevertheless, some of the interviewed subjects still consider the opening of the minority schools to non-Slovenian pupils as a "danger"; i.e., as a phenomenon that "spoils" the ethno-linguistic homogeneity of the Slovenian community. This kind of fear is clearly described by the following interview extract:

Int. 16: (...) The problem arises when the teacher in the kindergarten or in the primary school has two pupils who do not speak Slovenian. (...) He needs to speak Italian. Then of course the question is, whether this is a Slovenian school. It is not a Slovenian school! We can not allow this, as it is a negative process, which can cost us dearly (...). It is a sad situation, as in this case we spoil the study of the remaining ten children, who can speak Slovenian. 
B) Efforts towards the introduction of minority language teaching in primary schools with Italian as the language of instruction.

With regard to the introduction of Slovenian language teaching into the "majority" schools, in the last years important steps have been made. Since 1999, the National Law 482/99 "Legal Provisions Regarding the Protection of Historic Linguistic Minorities" has been offering to the schools in the Friuli Venezia Giulia Region the possibility of obtaining financial aid for the introduction of minority language courses, including, naturally, Slovenian courses. In spite of the initially poor interest in these possibilities, in the last years the requests for such courses have increased ${ }^{4}$. In addition, by the academic year 2009-2010, a lower secondary school in Trieste/Trst will for the first time introduce an optional course of Slovenian as the second European language within its regular didactic programme.

Most of the qualified observers stress the need to strengthen the efforts towards the systematic and institutionalized introduction of Slovenian language teaching in primary schools with Italian as the language of instruction. The introduction of Slovenian as one of the subjects in the majority schools will help the spread of the knowledge of the minority language and culture. Moreover, it would increase the prestige of the language at a local and regional level.

Int. 2: (...) The institutions shall promote the study of the Slovenian language as an optional subject in the various grades of the primary schools, or at least for some elements of culture mediation. This is already happening, but in very limited dimensions. If this intervention was institutionalised, so that Slovenian language and culture were part of the subjects in Italian schools, in a couple of decades we could get over these differences and raise the interest in Slovenian language and culture. (...)

Although this desire has been expressed by the majority of the interviewed subjects, there is at the same time a diffused opinion that a systematic introduction of Slovenian language courses in

4 According to the data collected by the Ministry of Public Education (www.miur.it), in the academic year 2004/2005, the approved didactic projects for the teaching of the Slovenian language were four, in the academic year 2005/2006 eight, and in the academic year 2006/2007 eleven. 
Italian schools would damage the minority schools and the Slovenian community in general. The fear is present that Slovenian schools would lose some number of pupils according to the logic of the following question: If schools with Italian as a teaching language offer optional courses in Slovenian, what would prevent ethnically Slovenian parents or parents from mixed marriages from enrolling their children into schools with Italian as a teaching language, that is given a wider choice of study fields and didactic programmes?

Int. 43: (...) I see no great mobilisation of the Slovene institutions for the introduction of the Slovene language in Italian schools. Everyone thinks that Slovene schools will lose something and that Italian parents will no longer enrol their children in Slovene schools. (...)

C) Diffusion and promotion of Slovenian language courses among non-Slovenian speaking adults.

Among the interviewed subjects, there is the common feeling that in recent years the interest of the majority population in Slovenian language acquisition has grown and that this is evident from the increasing attendance of the language courses offered by informal educational institutions.

Int. 37: (...) In the new conditions of change we noticed that the members of the majority community started to approach the Slovenian language. Interesting. (...) This is one of the positive results of this development, of this formation of a new, wider space in Europe. (...) I think that it is in our interest to do our best with various courses in order to meet the new needs.

The reasons for such an increase are several. The main one could be represented by economic and pragmatic factors, resulting from new employment and living options in neighbouring Slovenia after the recent abolition of the administrative border. A second motivation is the desire to acquire knowledge of the minority language, mainly in cases in which Slovenian was the ancestral mother tongue of ancestors. A third motivation arises from the mere desire to acquire knowledge of a new language and to enrich one's own communicative competences.

Int. 22: Some people assert that the motivation arises from the fact that their grandparents were Slovenes, even if this is not always the case. Of course, some of them need to 
learn the language or they already live or work in Slovenia. Others wish to learn the language in order to enrich their general culture.

Most of the interviewed subjects positively evaluate the increased number of Slovenian language courses, although some are critical to certain degree of improvisation in the didactic approaches adopted by the teachers.

Int. 19: (...) There are many courses, especially in the last years their number is growing and this fact shall be further developed, as I believe that the demand is higher than the offer, surely. (...) Our offer is I shall say improvised, sometimes. (...) I know many people who teach Slovenian to Italians, but they all follow their own teaching style.

D) Opening and promotion of the minority cultural production to Italian speaking audience.

Among the possible strategies for the spread of the Slovenian language and culture, a high number of interviewed subjects emphasize the need to open cultural events and initiatives organized by the Slovenian community to non-Slovenian speakers. In particular, it is suggested ensure the practice of the subtitling in the Italian language of the plays of the Slovenian Repertory Theatre (SSG), the most important minority cultural institution. The implementation of this strategy is perceived as stimulating the interest for acquiring knowledge of the Slovenian language and raising its prestige at the local level. Indeed, despite its current financial crisis, the production of the Slovenian Repertory Theatre has in the recent years become more and more recognisable within the whole regional cultural life.

Int. 8: (...) The most visible Slovenian high institution is the theatre, which offers bilingual plays with subtitles in Italian and thus spreads the promotion of the Slovenian culture (...).

Int. 28: (...) The idea of the subtitles vas very much criticised. (...) Someone said: "Now what, our theatre is no longer the temple of the Slovenian culture!" (...) But now, what have we reached? The Piccolo newspaper [= one of the most important newspapers in the Friuli Venezia Giulia Region] reports about every play in the Slovenian theatre. 
E) A professional approach towards the involvement of nonSlovenian subjects in the Slovenian associations and organizations and towards their acquisition of the minority language.

Difficulties and contradictions similar to those observed in relation to primary schools with Slovenian as the language of instruction towards non-Slovenian pupils can be found in the minority associations and organisations, particularly in the sports clubs, where the membership and the active participation of non-Slovenian speakers is continuously increasing.

As already mentioned before, the associations play a key role in the minority community, as they support the maintenance of the vitality of Slovenian language and identity. As they represent one of the "columns" of the Slovenian presence in the Friuli Venezia Giulia Region, the question of the involvement of non-Slovenian speakers in such key structures for the development of the minority community is at hand.

As regards the relation towards the treated problem, two categories of interviewed subjects emerge. The following extract represents the ones who are more indulgent towards the use of a second language within this traditional minority domain:

Int. 33: On the basis of my experience I can say that some members who worked within the framework of Slovenian associations and were Italians, have sometimes been treated not very well by our people and therefore left and abandoned their activity. This is extremely negative! Sometimes it is better to speak Italian when needed and include these people, who are willing to cooperate in our associations, as if they find themselves in a group of people, who speak Slovenian, it means that they wish to cooperate with this association. (...).

The second interview extract represents the ones who - on the contrary - strictly strive for the exclusive use of Slovenian and the direct maintenance of the so called "hard core" of the Slovenian community:

Int. 12: (...) Those who become members of a Slovenian association shall know that it is a Slovenian association. Our associations are founded on an ethnic basis, so it is important and compulsory that those who enrol can understand at least the basic Slovenian language. As, if we continue this way, welcoming in our sports associations good football players who can not speak Slovenian, and then for 
this reason we hire Italian coaches and we speak Italian, then it is better to suppress the association, as it is no longer Slovenian.

The quotations clearly show a bipolar partition within the Slovenian minority in Italy. It is a consequence of historical and ideological dissension ${ }^{5}$ which still significantly influence the current and, inevitably then, future development of the community. As regards the question of the policies to implement for the preservation of the minority language, there are two opposed visions. On one side, a part of the community stresses the need to expand the traditional target audiences to bilingual or non-Slovenian speakers, irrespective of whether they consider themselves as only Slovenians, have attended Slovenian schools or participate in Slovenian commemorative celebrations. On the other extreme are those who favour the maintenance of a "linguistically pure" minority, composed of loyal speakers of the minority language, preferably coming from Slovenian families, attending Slovenian schools and being active within the Slovenian associations. The data analysis also brought to light various stances, many which could, with regard to the two extremes, be considered "intermediate," and altogether reflect the vivid heterogeneity of the community itself. At the same time, however, the very diversity of opinion is a hindrance to the adoption of an adequate and coherent minority language planning strategy.

\section{Conclusions}

As reported by Brezigar (2009), a linguistic minority faces decline if its goal is only to retain its members and their future generations. The analysis of the language use patterns among the Slovenian community members, presented in the first section, has clearly revealed a slow, yet progressive advancing of the processes of shift towards the use of the Italian language. This paper postulates that if the community set the maintenance of its language as a fundamental objective, it would require not only the development

5 Because of the political divisions that followed the Second World War, the Slovenes have never succeeded in coming together on a single platform to plan the development of the community and its language. Even today the community operates under the banner of two central organizations: the secular left-wing Slovenian Cultural and Economic Union (SKGZ) and the catholic Council of Slovenian Organizations (SSO). 
of language planning activities aimed at maintaining the language among the members of the community, but also specific attention to the strategies for the acquisition of new potential speakers within the wider society.

This is a new and undoubtedly revolutionary perspective for a community that has been traditionally oriented towards the maintenance of the status quo. As the analysis of the in-depth interviews has showed, obstacles and fears towards a greater opening of the community boundaries towards people with a different mother tongue are still present amongst the Slovenes living in this area. They are the result of a not yet forgotten stormy past, marked by difficult relations with the majority group and its not yet soothed aspirations to adopt explicit or "tacit" linguistic assimilation policies for the local minorities.

Despite the new challenges generated by the recent sociopolitical developments in the Italian-Slovenian border area, the growing interest in the Slovenian language at a regional level and the increasing opportunities for the language to be used in social life, the Slovenian community still seems to hesitate in assuming a leading role in determining its own destiny. The results of the qualitative study have shown that there is no lack of ideas and good intentions; indeed there seems to be a lack of bravery and especially of a tangible willingness to put them into practice. For this to happen a united approach is called for, as the Slovenian language community needs to have a common vision of its own development.

\section{Address:}

Devan Jagodic

SLORI - Slovenski raziskovalni inštitut

Piazza Giotti 1

34133 Trieste

Italy

E-mail: d.jagodic@slori.org

\section{References}

Baker, C. And S. P. Jones (1998) Encyclopedia of bilingualism and bilingual education. Clevedon: Multilingual Matters.

Bajc, G. et al. (2008) Pre-misliti manjðino. Pogledi reprezentativnih predstavnikov Slovencev $v$ Italiji in pravno-politièni okvir. Trieste-Koper: Uni- 
versity of Primorska-Science and Research Centre of Koper-Slovene Research Institute.

Bogatec, N., ed. (2004a) Slovene. The Slovene language in education in Italy. Ljouwert/Leeuwarden: Mercator Education.

Brezigar, S. (2009) "The Slovene language in Italy: paths to a value-added position". In S. Pertot, T. Priestly, and C. Williams, eds. Rights, promotion and integration issues for minority languages in Europe, 207-215. Basingstoke: Palgrave.

Crystal, D. (2000) Language death. Cambridge: Cambridge University Press.

De Klerk, V. (2000) "Language shift in Grahamstown: a case study of selected Xhosa speakers". International Journal of Sociology of Language 146, 87-110.

Fasold, R. (1984) The sociolinguistics of society. Oxford: Blackwell.

Fishman, J. (1971) The sociology of language. Rowley, MA: Newbury House

Jagodic, D., ed. (2008) Mladi v èezmejnem prostoru / I giovani nell'area transfrontaliera. Trieste: SDZPI-IRSIP.

Kauèiè-Baða, M. (1997) "Where do Slovenes speak Slovene and to whom?". International Journal of Sociology of Language 124, 51-73.

Ministero dell'Istruzione, dell'Universit? e della Ricerca (MIUR). Ministry of Education, University and Research, www.miur.it.

Kokkuvõte. Devan Jagodic: Keele säilimise ja -vahetuse vahel: sloveeni kogukond Itaalias täna ja homme. Artikkel keskendub keele säilimisele ja -vahetusele sloveeni kogukonnas Põhja-Itaalias, lähtudes praegustest ja tulevikuväljavaadetest, ning esitleb kahe empiirilise uurimuse tulemusi. Esimene neist on kvantitatiivne analüüs sloveeni kogukonna liikmete keelelisest käitumisest ning selle eesmärk on anda ülevaade vähemuskeele säilimise tasemest või järkjärgulisest vahetumisest itaalia keele vastu. Põlvkondadevaheline võrdlus seab keskmesse mõned erinevused kahes eri vanusegrupis ja osutab variaablitele, mis võimaldavad nendevahelist koostööd. Teine uurimus tegeleb väljakutsetega, millega sloveeni kogukond kokku puutub, et julgustada vähemuskeele kasutamist sloveeni keelt mitterääkivate elanike hulgas. Tuginedes kvalitatiivsetele andmetele, mis on saadud rea süvaintervjuude läbiviimisel Sloveenia poliitiliste, kultuuriliste ja majanduslike organisatsioonide esindajatega Itaalias, on uurimuse eesmärk selgitada välja võimalikud strateegiad sloveeni keele levikuks ja edendamiseks laiemas ühiskonnas.

Märksõnad: vähemuskeeled, keele säilimine ja -vahetus, keelekasutus, keelekorraldus, sloveeni kogukond Itaalias, Euroopa integratsioon 
